\title{
PERENCANAAN STRATEGIS SISTEM INFORMASI KLINIK KECANTIKAN DENGAN PENDEKATAN DAN WARD AND PEPPARD MODEL (Studi Kasus : PT. Virgina Estetika (Farina Beauty Clinic))
}

\author{
Andi Pranata \\ Sekolah Tinggi Manajemen Infromatika dan Komputer LIKMI \\ Jl. Ir. H. Juanda No. 96, Lebakgede, Bandung \\ andics49@gmail.com
}

\begin{abstract}
ABSTRAK
PT.Virgina Estetika (Farina Beauty Clinic) merupakan organisasi atau perusahaan yang bergerak di bidang penyedia jasa pelayanan perawatan kulit wajah dan tubuh. Untuk bisa mendapatkan keunggulan bersaing dan dapat bertahan dalam persaingan yang ketat, strategi yang dapat dilakukan Klinik kecantikan adalah dengan differentiation dan cost reduction. Salah satu hal yang bisa dilakukan untuk cost- reduction adalah dengan menjadikan proses bisnis yang ada di Klinik Kecantika menjadi lebih efisien, salah satu hal yang bisa dimanfaatkan untuk efisiensi adalah SI/TI. Secara garis besar penelitian ini merupakan upaya untuk membangun suatu perencanaan strategis sistem informasi beserta portofolio aplikasi di PT. Virgina Estetika (Farina Beauty Clinic) yang bisa memberikan kontribusi yang optimal, terintegrasi dengan baik dan inovatif yang bisa menyatukan keseluruhan aspek pendukung dalam pencapaian strategi bisnis klinik untuk meningkatkan nilai kompetitifnya dalam jasa pelayanan kesehatan.

Dalam penyusunan kerangka kerja perencanaan strategis sistem informasi menggunakan pendekatan Ward and Peppard Model dan dalam mengevaluasi penjabaran perencanaan strategis sistem informasi dan strategi bisnis menggunakan Balance Scorecard IT. Beberapa metode analisis seperti, Value Chain Analysis, SWOT Analysis, PEST Analysis dan Five Force Model Analysis digunakan untuk menganalisis lingkungan bisnis internal dan eksternal. Strategic Grid McFarlan Analysis digunakan untuk memetakan portofolio aplikasi. Pada akhirnya penelitian ini menghasilkan sebuah rekomendasi untuk organisasi berupa prioritas pembangunan yang terbagi menjadi dua hal- hal terkait, pembentukan unit SI/TI dan pengembangan portofolio aplikasi yang akan mendukung keberlangsungan proses bisnis PT. Virgina Estetika (Farina Beauty Clinic) Karawang.
\end{abstract}

Kata Kunci : Perencanaan Strategis SI, Ward and Peppard Model, Balanced Scorecard.

\section{PENDAHULUAN}

\subsection{Latar Belakang}

Perkembangan sistem informasi yang begitu pesat memberikan dampak yang begitu besar bagi mutu suatu organisasi atau perusahaan. Dalam upaya meningkatkan mutu diperlukan sistem informasi yang mendukung semua unit kerja di PT.Virgina Estetika.

Untuk mencapai efektifitas dan efisiensi sistem informasi PT.Virgina Estetika, peranan perencanaan strategis sistem informasi perlu dikelola dengan tepat sehingga visi dan misi perusahaan tercapai. Pemanfaatan secara optimal penggunaan teknologi informasi 
sehinga mampu bersaing dengan perusahaan lainnya. Kebutuhan data dan informasi yang cepat, tepat serta akurat sangat diperlukan. Menghadapi persaingan yang semakin ketat perlu ditunjang dengan perencanaan strategis sistem informasi ( IT Strategic Plan). Untuk dapat meningkatkan nilai (value) dan menciptakan keunggulan kompetitif (competitive advantage) serta mengupayakan growth (pertumbuhan) yang berkesinambungan diperlukan suatu kerangka kerja berkesinambungan diperlukan suatu kerangka kerja yang dapat memberikan peran strategis sistem informasi atau teknologi informasi yang baik untuk PT.Virgina Estetika (Persero). Perencanaan strategis sistem informasi yang terintegrasi memudahkan pengelolaan sumber daya yang ada dan akan menghasilkan informasi yang akurat, tepat waktu dan dapat digunakan secara bersama oleh pihak-pihak yang berkepentingan.

\subsection{Rumusan Masalah}

Berikut ini merupakan permasalahan yang akan menjadi perhatian utama dalam penelitian ini adalah:

a. Bagaimana membangun perencanaan strategis sistem informasi yang mampu beradaptasi dan selaras dengan strategi bisnis PT.Virgina Estetika (Farina Beauty Clinic) sehingga dengan demikian visi, misi dan tujuan PT.Virgina Estetika (Farina Beauty Clinic) dapat tercapai?

b. Bagaimana hasil akhir perencanaan strategis sistem informasi di PT.Virigina Estetika (Farina Beauty Clinic) berupa aplikasi portofolio ?

\subsection{Tujuan Penelitian}

Tujuan dari penelitian ini adalah:

a. Menganalisis strategi sistem informasi yang berjalan di PT.Virgina Estetika (Farina Beauty Clininc) Karawang, kemudian menilai apakah dengan strategi sistem informasi yang sudah diterapkan tersebut dapat mendukung Klinik untuk bersaing dengan penyedia jasa di bidang pelayanan kesehatan lainnya.

b. Memberikan bentuk usulan aplikasi portofolio yang akan diterapkan di PT.Virgina Estetika (Farina Beauty Clinic).

\subsection{Batasan Masalah}

Karena pembahasan mengenai sistem informasi sangat luas, maka untuk lebih mengarahkan penelitian ini yang memiliki batasan masalah, yaitu:

a. Analisa strategi bisnis internal dan eksternal pada perusahan

b. Analisa pesaing, pemasok, pendatang baru, dan supplier yang mendukung kinerja proses bisnis perusahaan.

c. Perencanaan strategi sistem informasi dan teknologi informasi yang mendukung penelitian aplikasi Portofolio.

\section{TINJAUAN PUSTAKA}

Strategi pada dasarnya adalah suatu bentuk kegiatan atau cara pendekatan yang diterapkan manajer untuk memuaskan pelanggannya, membentuk posisi pasar yang menarik dan mencapai sasaran oganisasi

Membangun strategi sistem informasi dan teknologi informasi berarti berpikir strategis dan berencana untuk efektivitas proses manajemen jangka panjang dan berpengaruh kepada informasi yang optimal dalam berbagai bentuk sistem informasi maupun teknologi informasi yang menggunakan sistem manual maupun sistem komputer, teknologi komputer dan telekomunikasi serta aspek organisasi dalam manajemen sistem informasi atau teknologi informasi. 
Menurut Ward and Peppard (2003:153) tentang perencanaan strategis yaitu, "perencanaan strategis dan kerangka kerja bagi manajemen untuk menyelaraskan strategi SI/TI dengan strategi bisnis, bahkan digunakan untuk mencari kesempatan baru melalui penerapan teknologi yang inovatif'.

Kesimpulan dari perencanaan strategi sistem informasi adalah suatu proses untuk menyusun perencanaan, penggunaan dan implementasi sistem informasi dan teknologi informasi secara komprehensif pada suatu organisasi yang sejalan dengan strategi bisnis organisasi untuk mendukung pencapaian tujuan organisasi secara efektif dan efisien. Strategi sistem informasi dan teknologi informasi hendaknya mengarah pada kinerja sistem yang terintegrasi untuk menghasilkan informasi yang akurat yang dapat digunakan sebagai masukan dalam mengambil keputusan.

Model perencanaan Ward and Peppard dimulai dari investasi teknologi informasi yang sudah ada dan kurang bermanfaat dalam menunjang visi dan misi perusahaan dan memanfaatkan teknologi informasi terbaru yang dapat meningkatkan keunggulan kompetitif dari perusahaan atau organisasi. Perencanaan strategis selain memanfaatkan teknologi juga harus berdasarkan kebutuhan bisnis.

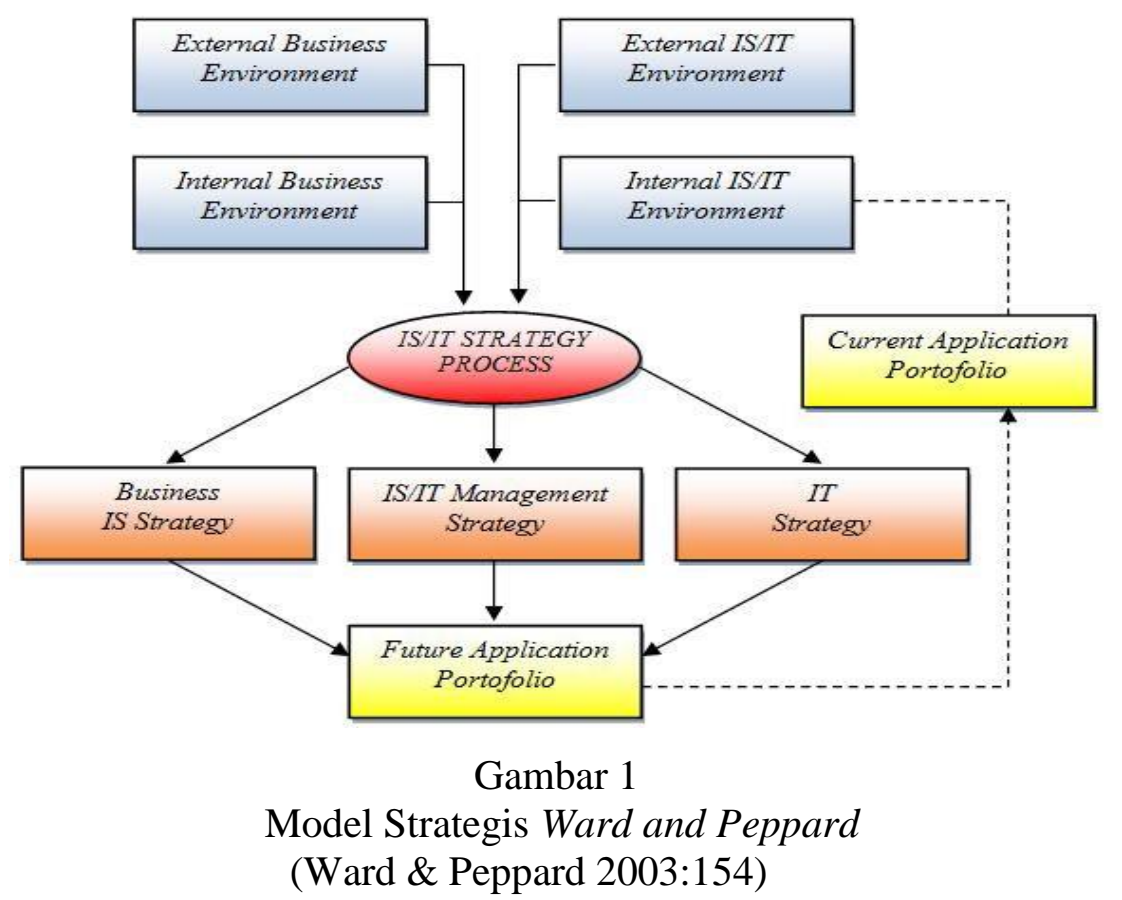

Pada gambar 1 ditampilkan model strategis Ward and Peppard dalam perencanaan sistem dan teknlogi informasi bagian-bagian penting dalam penyusunan IS/IT Strategic Plan. Tahapan pada Ward and Peppard terdiri dari tahapan masukan dan tahapan keluaran. Kerangka kerja dalam menyusun perencanaan strategik sistem informasi berdasarkan metodologi ini, memerlukan analisis terhadap empat masukan (input).

\section{METODE PENELITIAN}

Metodologi perencanaan strategis SI/TI yang akan digunakan adalah metode perencanaan strategis berdasarkan Ward and Peppard Model. Dalam model ini terdapat 2 tahapan yaitu tahapan input (masukan) dan output (keluaran). Tahapan input yaitu analisis lingkungan bisnis internal, analisis lingkungan bisnis eksternal, analisis lingkungan SI/TI internal dan analisis lingkungan SI/TI eksternal. Untuk tahapan output yaitu strategi SI bisnis, strategi TI dan strategi manajemen SI/TI. Beberapa teknik/metode yang digunakan 
adalah Value Chain Analysis, SWOT Analysis, PEST Analysis, Five Forces Model Analysis dan Strategic Grid McFarlan Analysis. Sedangkan dalam mengevaluasi penjabaran perencanaan strategis sistem informasi dan strategi bisnis menggunakan pendekatan Balance Scorecard.

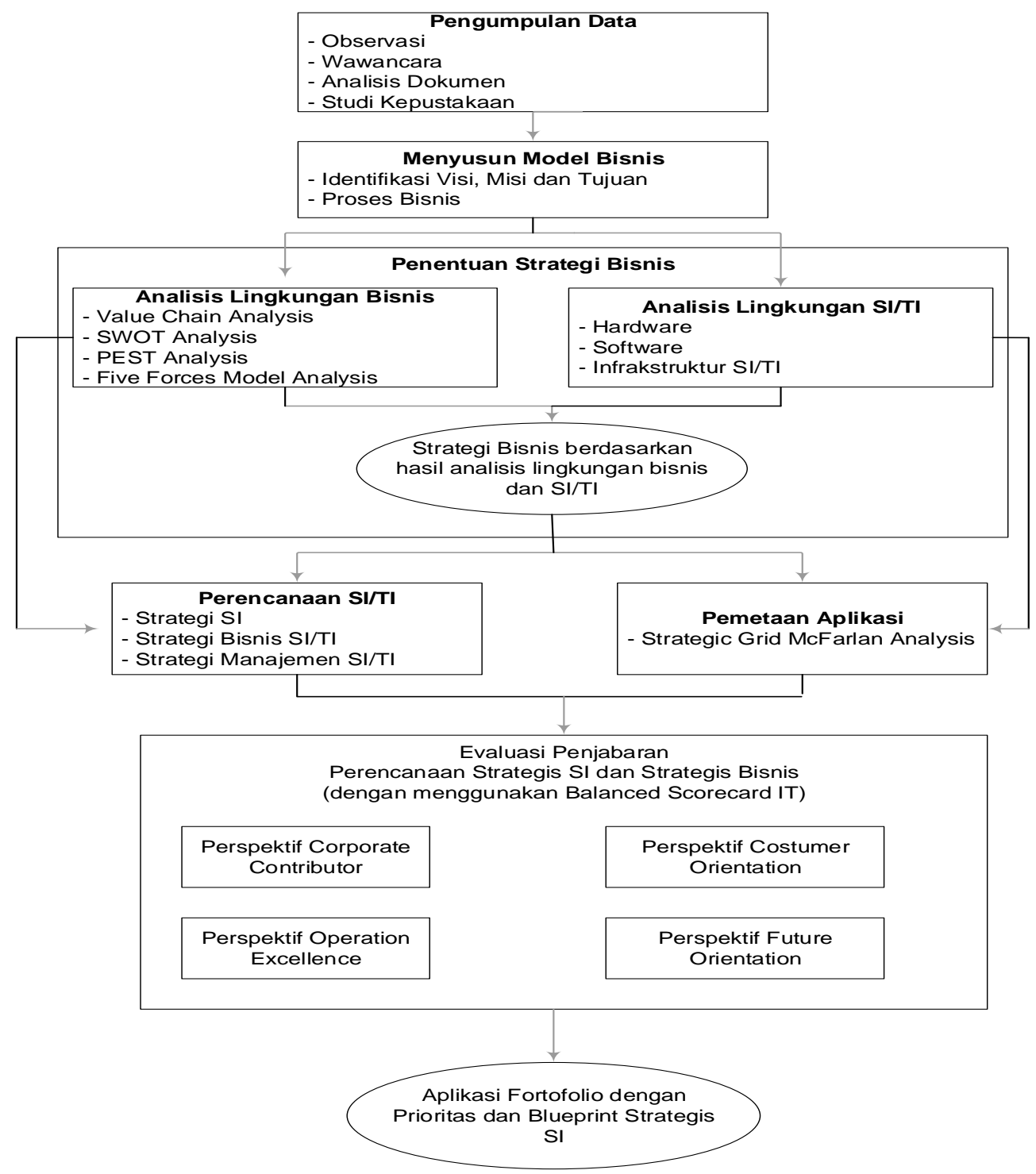

Gambar 2

Metodologi Penelitian

\section{MODEL BISNIS PT. VIRGINA ESTETIKA}

Mengidentifikasi visi, misi dan tujuan yang ingin dicapai Farina Beauty Clinic, kemudian menyusun proses bisnis apa saja yang ada di Farina Beauty Clinic Karawang dan menggambarkannya ke dalam model proses bisnis. 


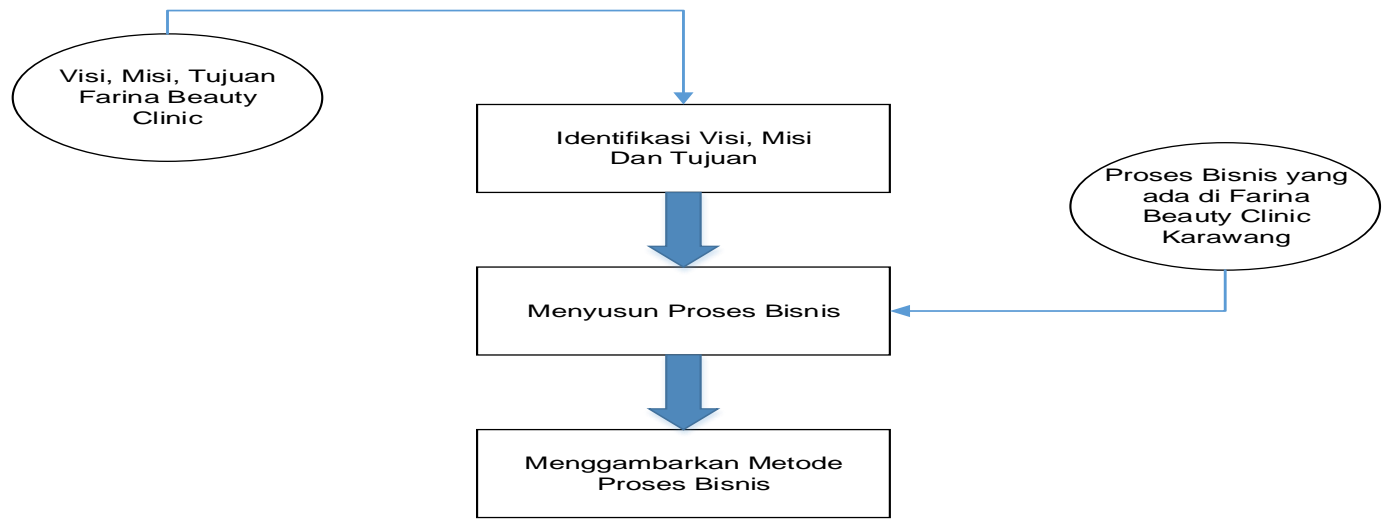

Gambar 3

Kerangka Penyusunan Model Bisnis Farina Beauty Clinic.

Pada Gambar 4 dipaparkan visi dan misi yang merupakan tahapan paling awal untuk menyusun model bisnis pada Farina Beauty Clinic.

Visi :

Menjadikan Farina Beauty Clinic sebagai clinic perawatan kulit wajah dan tubuh dan tubuh terbaik, penanganan dan tenaga yang paling prestisius dan bernilai tambah, terbaik, terbesar, dan

Misi :
1. Memperbaiki tingkat kesadaran masyarakat mengenai
pentingnya menjaga dan merawat kesehatan kulit wajah dan
tubuh.
2. Menjadikan Farina Beauty Clinic sebagai sebuah pusat
perawatan kulit wajah dan tubuh dan tubuh yang memiliki
pelayanan yang ramah, nyaman, mewah, profesional, dengan
harga terjangkau oleh semua lapisan masyarakat kota
Karawang.
3. Menyediakan pelayanan perawatan kulit wajah dan tubuh,
tubuh dan rambut yang lengkap untuk memenuhi kebutuhan
para wanita.

Gambar 4

Visi dan Misi

Pada PT. Virgina Estetika (Farina Beauty Clinic) terdapat beberapa proses bisnis yang dilakukan, yaitu sebagai berikut:

1. Facial

Untuk memiliki kulit wajah yang bersih, putih dan bebas dari jerawat, salah satu treatment yang dapat dilakukan adalah dengan melakukan facial.

2. Beauty Clinic

Perawatan kecantikan merupakan pelayaan untuk melakukan beberapa prosedur yang bertujuan meningkatkan penampilan agar wajah lebih segar dan bersih.

3. Salon dan SPA

Spa merupakan perawatan kecantikan yang dapat menyegarkan tubuh serta pikiran, meningkatkan kesehatan psikir dan psikologis. 


\section{ANALISIS BISNIS DAN VALUE CHAIN}

\subsection{Analisa Value Chain PT. Virgina Estetika}

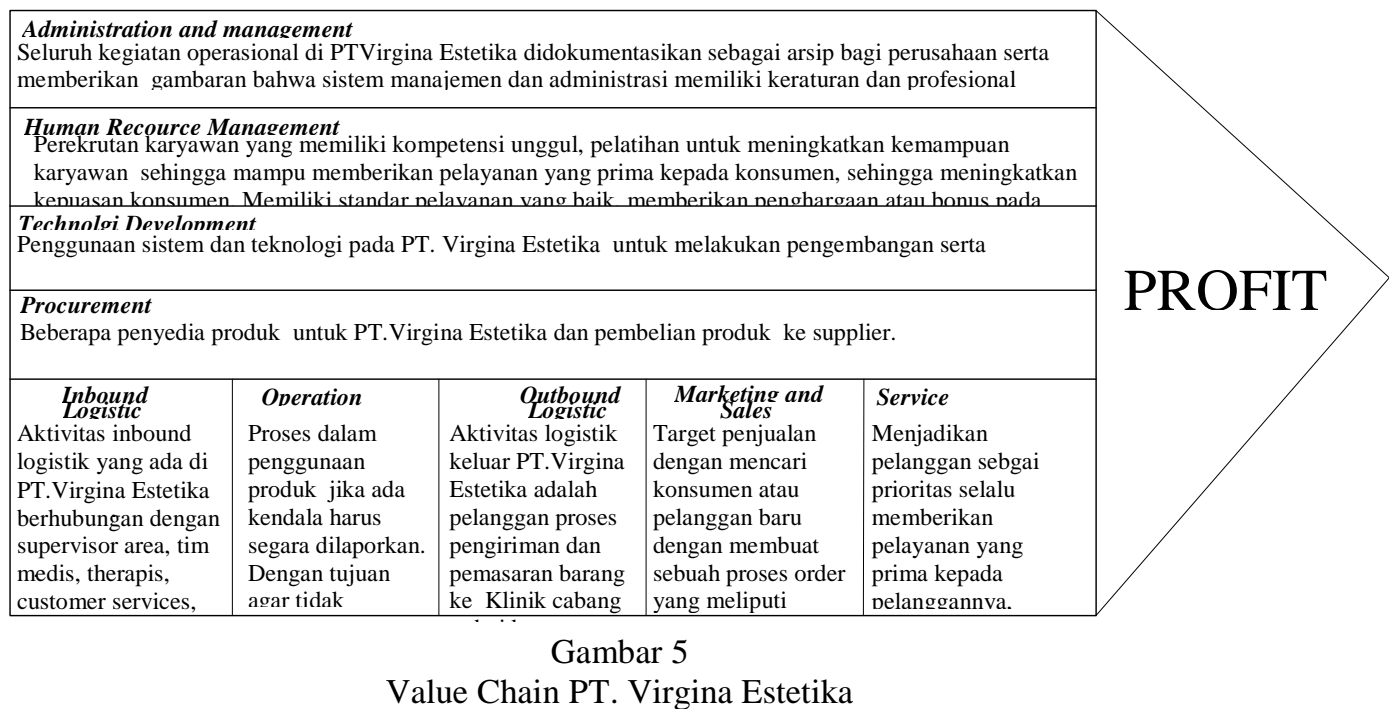

\subsection{Analisa Bisnis Eksternal Dengan Menggunakan PEST Analysis}

PEST analysis berguna untuk mengevaluasi variabel lingkungan eksternal untuk mengidentifikasi peluang dan risiko umum dari strategi tertentu, karena perubahan faktorfaktor ini dapat menyebabkan transformasi industri yang signifikan, terutama dalam jangka panjang. Berikut ini faktor-faktor eksternal yang mempengaruhi proses bisnis PT. Virgina Estetika (Farina Beauty Clinic) berdasarkan PEST Analyisis:

1. Political factor

Faktor politik merupakan faktor yang dapat berpengaruh terhadap keadaan ekonomi dan beberapa industri lain, seperti adanya kebijakan dari pemerintah terhadap suatu negara atau wilayah akan berpengaruh terhadap sektor keuangan, bisnis dan ekonomi Negara tersebut.

2. Economic factor

Keadaan ekonomi yang mempengaruhi industri perawatan kulit wajah dan tubuh di Indonesia adalah naiknya pendapatan per kapita masyarakat Indonesia dari tahun 2017 ke tahun 2018. BPS pada situsnya ( www.bps.go.id ) mencatat pendapatan per kapita pada 2017 mencapai Rp 12,45 juta atau 1.308 dolar AS mengalami kenaikan daripada 2018 yang mencapai Rp 10,51 juta atau 1.166 dolar AS. Sedangkan kenaikan pendapatan per kapita pada 2019 mencapai hampir 20\% yaitu 1.562 dolar AS.

3. Social factor

Lingkungan sosial budaya yang mempengaruhi industri perawatan kulit wajah dan tubuh di Indonesia khususnya Karawang saat ini adalah adanya perubahan tren pada pola hidup masyarakat perkotaan yang sekarang baik wanita maupun pria lebih memperhatikan penampilan mereka

4. Technological factor

Menurut Wawan Wardiana (http://eprints.rclis.org), perkembangan teknologi dapat meningkatkan kinerja dan memungkinkan berbagai kegiatan dapat dilaksanakan dengan cepat, tepat dan akurat, sehingga akhirnya akan meningkatkan produktivitas 


\subsection{Analisis Bisnis Internal - Eksternal Dengan Menggunakan SWOT Analysis}

Analisis menggunakan matriks SWOT (Strenght, Weaknes, Opportunities, Threats). Berikut hasil analisis SWOT yang telah dilakukan

a. Strategi SO (Strenght - Opportunities)

Strategi SO (Strenght - Opportunities) merupakan strategi lingkungan internal pada analisis SWOT yaitu menggunakan kekuatan dengan memanfaatkan peluang. Berikut ini tabel Strategi SO (Strenght - Opportunities) berdasarkan identifikasi SWOT.

Tabel 1. Strategi SO (Strenght - Opportunities)

\begin{tabular}{|c|c|c|c|c|}
\hline No & Strategi SO & Deskripsi & CSF & $\begin{array}{l}\text { SI/TI yang } \\
\text { diusulkan }\end{array}$ \\
\hline 1 & $\begin{array}{l}\text { Pengembangan } \\
\text { sistem penyebaran } \\
\text { pengetahuan yang } \\
\text { dimiliki SDM } \\
\text { senior kepada } \\
\text { SDM junior }\end{array}$ & $\begin{array}{l}\text { Melakukan } \\
\text { pelatihan } \\
\text { terhadap } \\
\text { karyawan } \\
\text { untuk } \\
\text { meningkatkan } \\
\text { keahlian. }\end{array}$ & $\begin{array}{l}\text { PT.Virigina } \\
\text { Estetika harus } \\
\text { menyediakan } \\
\text { dukungan dan } \\
\text { Fasilitas untuk } \\
\text { meningkatkan } \\
\text { produktivitas } \\
\text { team. }\end{array}$ & $\begin{array}{l}\text { Aplikasi SDM } \\
\text { PT.Virgina } \\
\text { Estetika }\end{array}$ \\
\hline 2 & $\begin{array}{l}\text { Pengembangan } \\
\text { fasilitas pelayanan } \\
\text { guna } \\
\text { meningkatkan } \\
\text { kepuasan pasien } \\
\text { atau masyarakat }\end{array}$ & $\begin{array}{l}\text { Mendukung } \\
\text { karyawan } \\
\text { dengan } \\
\text { menyediakan } \\
\text { alat-alat yang } \\
\text { dibutuhkan } \\
\text { untuk } \\
\text { melakukan } \\
\text { tugasnya. }\end{array}$ & $\begin{array}{l}\text { Memberi } \\
\text { wewenang } \\
\text { kepada } \\
\text { karyawan } \\
\text { untuk } \\
\text { melakukan } \\
\text { proses kerja } \\
\text { dengan displin }\end{array}$ & $\begin{array}{l}\text { Aplikasi } \\
\text { Decision } \\
\text { support system } \\
\text { kinerja } \\
\text { PT.Virgina } \\
\text { Estetika }\end{array}$ \\
\hline 3 & $\begin{array}{l}\text { Pengembangan } \\
\text { sistem untuk } \\
\text { menilai kinerja } \\
\text { setiap karyawan } \\
\text { sehingga dapat } \\
\text { memonitor oleh } \\
\text { pihak top } \\
\text { management } \\
\text { PT.Virgina } \\
\text { Estetika. }\end{array}$ & $\begin{array}{l}\text { Kemudahan } \\
\text { akses data } \\
\text { karyawan } \\
\text { dibagian HRD } \\
\text { atau } \\
\text { kepegawaian. }\end{array}$ & $\begin{array}{l}\text { Bagian } \\
\text { kepegawaian } \\
\text { harus } \\
\text { menyediakan } \\
\text { data setiap } \\
\text { karyawan } \\
\text { yang } \\
\text { diperlukan } \\
\text { oleh pihak top } \\
\text { management } \\
\text { seperti data } \\
\text { absensi, data } \\
\text { prestasi, dll. }\end{array}$ & $\begin{array}{l}\text { Aplikasi } \\
\text { Decision } \\
\text { support system } \\
\text { kinerja } \\
\text { PT.Virgina } \\
\text { Estetika }\end{array}$ \\
\hline 5 & $\begin{array}{l}\text { Pengembangan } \\
\text { fasilitas } \\
\text { pengorganisasian } \\
\text { data yang } \\
\text { tersentral agar } \\
\text { dapat digunakan }\end{array}$ & $\begin{array}{l}\text { Data setiap } \\
\text { departement } \\
\text { harus } \\
\text { terintegrasi } \\
\text { satu sama lain. }\end{array}$ & $\begin{array}{l}\text { Membangun } \\
\text { satu main } \\
\text { server } \\
\text { database } \\
\text { dalam PT. } \\
\text { Virgina }\end{array}$ & $\begin{array}{l}\text { Aplikasi } \\
\text { Database } \\
\text { Terdistribusikan }\end{array}$ \\
\hline
\end{tabular}




\begin{tabular}{|l|l|l|l|l|}
\hline No & \multicolumn{1}{|c|}{ Strategi SO } & \multicolumn{1}{|c|}{ Deskripsi } & \multicolumn{1}{c|}{ CSF } & \multicolumn{1}{|c|}{$\begin{array}{l}\text { SI/TI yang } \\
\text { diusulkan }\end{array}$} \\
\hline $\begin{array}{l}\text { disetiap } \\
\text { departemen yang } \\
\text { membutuhkan }\end{array}$ & $\begin{array}{l}\text { Estetika } \\
\text { fasilitas yang } \\
\text { dapat menyimpan } \\
\text { setiap dokumen }\end{array}$ & $\begin{array}{l}\text { Memberikan } \\
\text { kemudahan } \\
\text { untuk SDM } \\
\text { agar dapat } \\
\text { mengupload } \\
\text { atau } \\
\text { mendownload } \\
\text { dokumen }\end{array}$ & $\begin{array}{l}\text { Membangun } \\
\text { satu main } \\
\text { server } \\
\text { database di } \\
\text { PT.Virgina } \\
\text { Estetika } \\
\text { (Farina } \\
\text { Beauty Clinic) }\end{array}$ & $\begin{array}{l}\text { Aplikasi sistem } \\
\text { dokumen PT. } \\
\text { Virgina Estetika } \\
\text { (Farina Beauty } \\
\text { Clinic) }\end{array}$ \\
\hline 6 & & & \\
\hline
\end{tabular}

b. Strategi WO (weakness -Opportunities)

Strategi WO (Weakness - Oppurtunities) merupakan strategi lingkungan internal pada analisis SWOT yaitu menggunakan kekuatan dengan memanfaatkan peluang. Berikut ini tabel strategi WO (Weakness - Opportunities) berdasarkan identifikasi SWOT.

Tabel 2. Strategi WO (Weakness - Opportunities)

\begin{tabular}{|c|c|c|c|c|}
\hline No & Strategi WO & Deskripsi & CSF & $\begin{array}{l}\text { SI/TI yang } \\
\text { diusulkan }\end{array}$ \\
\hline 1 & $\begin{array}{l}\text { Pemanfaatan } \\
\text { kerjasama dengan } \\
\text { badan pemerintah } \\
\text { seperti BPJS }\end{array}$ & $\begin{array}{l}\text { Pemanfaatan } \\
\text { kerjasama dengan } \\
\text { badan pemerintah } \\
\text { seperti BPJS guna } \\
\text { meningkatkan } \\
\text { relasi dan manfaat } \\
\text { yang dirasakan } \\
\text { oleh masyarakat. }\end{array}$ & $\begin{array}{l}\text { PT. Virgina } \\
\text { Estetika } \\
\text { (Farina } \\
\text { Beauty Clinic) } \\
\text { memanfaatkan } \\
\text { kerjasama } \\
\text { dengan } \\
\text { pemerintah } \\
\text { untuk } \\
\text { meningkatkan } \\
\text { jumlah } \\
\text { konsumen }\end{array}$ & $\begin{array}{l}\text { Aplikasi } \\
\text { keuangan }\end{array}$ \\
\hline 2 & $\begin{array}{l}\text { Meningkatkan } \\
\text { sistem strategis } \\
\text { layanan perawatan } \\
\text { wajah Efektif dan } \\
\text { efisien }\end{array}$ & $\begin{array}{l}\text { Pelayanan } \\
\text { dilakukan untuk } \\
\text { menyebarkan } \\
\text { informasi } \\
\text { Pelayanan } \\
\text { perawatan kulit } \\
\text { wajah terhadap } \\
\text { masyarakat }\end{array}$ & $\begin{array}{l}\text { PT. Virgina } \\
\text { Estetika } \\
\text { Harus } \\
\text { membuat } \\
\text { sistem } \\
\text { informasi } \\
\text { pelayanan } \\
\text { perawatan } \\
\text { kulit wajah } \\
\text { terhadap } \\
\text { pelanggan. }\end{array}$ & $\begin{array}{l}\text { - Aplikasi } \\
\text { sistem } \\
\text { informasi } \\
\text { pelayanan } \\
\text { - Aplikasi } \\
\text { Rekam Medis } \\
\text { - Aplikasi } \\
\text { Apotek }\end{array}$ \\
\hline
\end{tabular}


c. Strategi ST (Strength - Threats)

Strategi ST (Strength - Threats) merupakan strategi lingkungan internal pada analisis SWOT yaitu menggunakan kekuatan dengan memanfaatkan peluang. Berikut ini tabel Strategi ST (Strength - Threats) berdasarlan identifikasi SWOT, yaitu :

Tabel 3. Strategi ST (Strength - Threats)

\begin{tabular}{|c|c|c|c|c|}
\hline No & Strategi ST & Deskripsi & CSF & $\begin{array}{l}\text { SI/TI yang } \\
\text { diusulkan }\end{array}$ \\
\hline 1 & $\begin{array}{l}\text { Pemanfaatan } \\
\text { anggaran untuk } \\
\text { penyediaan fasilitas } \\
\text { dan infrastruktur } \\
\text { PT.Virgina Estetika } \\
\text { (Farina Beauty } \\
\text { Clinic) }\end{array}$ & $\begin{array}{l}\text { Pemanfaatan } \\
\text { anggaran untuk } \\
\text { penyediaan } \\
\text { fasilitas dan } \\
\text { infrastruktur PT. } \\
\text { Virgina Estetika } \\
\text { (Farina Beauty } \\
\text { Clinic) dalam } \\
\text { pelayan } \\
\text { perawatan kulit } \\
\text { wajah dan badan. }\end{array}$ & $\begin{array}{l}\text { PT. Virgina } \\
\text { Estetika } \\
\text { (Farina } \\
\text { Beauty } \\
\text { Clinic) harus } \\
\text { menyediakan } \\
\text { fasilitas dan } \\
\text { infrastruktur } \\
\text { klinik untuk } \\
\text { pelayanan } \\
\text { perawatan } \\
\text { kulit wajah } \\
\text { dan badan }\end{array}$ & $\begin{array}{l}\text { Aplikasi } \\
\text { keuangan } \\
\text { Aplikasi } \\
\text { inventaris } \\
\\
\text { Aplikasi } \\
\text { sistem } \\
\text { informasi } \\
\text { pelayanan }\end{array}$ \\
\hline 2 & $\begin{array}{l}\text { Pemanfaatan } \\
\text { anggaran untuk } \\
\text { menyediakan } \\
\text { fasilitas yang dapat } \\
\text { diakses oleh } \\
\text { pimpinan untuk } \\
\text { dapat mendukung } \\
\text { keputusan jangka } \\
\text { panjang }\end{array}$ & $\begin{array}{l}\text { Pimpinan harus } \\
\text { mempunyai } \\
\text { sistem informasi } \\
\text { untuk mengakses } \\
\text { dan mengecek } \\
\text { fasilitas yang ada } \\
\text { di PT. Virgina } \\
\text { Estetika (Farina } \\
\text { Beaut Clinic) }\end{array}$ & $\begin{array}{l}\text { PT. Virgina } \\
\text { Estetika harus } \\
\text { menyediakan } \\
\text { sistem } \\
\text { informasi } \\
\text { pengadaan } \\
\text { fasilitas. }\end{array}$ & $\begin{array}{l}\text { Aplikasi } \\
\text { sistem } \\
\text { informasi } \\
\text { Eksekutif } \\
\\
\text { Aplikasi } \\
\text { Inventaris }\end{array}$ \\
\hline 3 & $\begin{array}{l}\text { Pengembangan } \\
\text { sistem yang dapat } \\
\text { membantu } \\
\text { diagnosis penyakit } \\
\text { kulit }\end{array}$ & $\begin{array}{l}\text { Penyediaan sistem } \\
\text { diagnosis untuk } \\
\text { membantu dokter }\end{array}$ & $\begin{array}{l}\text { PT. Virgina } \\
\text { Estetika } \\
\text { (Farina } \\
\text { Beauty } \\
\text { Clinic) harus } \\
\text { menyediakan } \\
\text { sarana untuk } \\
\text { membantu } \\
\text { diagnosis } \\
\text { penyakit kulit }\end{array}$ & $\begin{array}{l}\text { Aplikasi } \\
\text { Expert system } \\
\text { diagnosa } \\
\text { penyakit }\end{array}$ \\
\hline
\end{tabular}

\section{d. Strategi WT (Weakness - Threats)}

Strategi WT (Weakness - Threats) merupakan strategi lingkungan internal pada analisis SWOT yaitu menggunakan kekuatan yang memanfaatkan peluang. Berikut ini tabel strategi WT (Weakness - Threats) berdasarkan identifikasi SWOT, sebagai berikut : 
Tabel 4.5 Strategi WT (Weakness - Threats)

\begin{tabular}{|c|c|c|c|c|}
\hline No & Strategi WT & Deskripsi & CSF & $\begin{array}{l}\text { SI/TI yang } \\
\text { diusulkan }\end{array}$ \\
\hline 1 & $\begin{array}{l}\text { Meningkatkan } \\
\text { distribusi obat, alat } \\
\text { medis yang lebih } \\
\text { efektif dan efisien } \\
\text { sehingga } \\
\text { ketersediaannya } \\
\text { tepat waktu }\end{array}$ & $\begin{array}{l}\text { Peningkatan } \\
\text { dilakukan guna } \\
\text { mengetahui } \\
\text { ketersediaan } \\
\text { obat, fasilitas dan } \\
\text { alat medis }\end{array}$ & $\begin{array}{l}\text { PT.Virgina } \\
\text { Estetika (Farina } \\
\text { Beauty Clinic) } \\
\text { harus } \\
\text { membangun } \\
\text { sistem infromasi } \\
\text { terintegrasi } \\
\text { mengenai } \\
\text { pengelolaan } \\
\text { ketersediaan } \\
\text { obat, fasilitas dan } \\
\text { alat medis }\end{array}$ & $\begin{array}{l}\text { Aplikasi } \\
\text { supply chain } \\
\text { management }\end{array}$ \\
\hline 2 & $\begin{array}{l}\text { Meningkatkan } \\
\text { pelayanan yang } \\
\text { lebih efektif dan } \\
\text { efisien serta } \\
\text { meminimalkan } \\
\text { kesalahan }\end{array}$ & $\begin{array}{l}\text { Hal ini } \\
\text { disebabkan data- } \\
\text { data yang tidak } \\
\text { akurat, salah } \\
\text { menggunakan } \\
\text { aplikasi namun } \\
\text { Belum } \\
\text { terintergrasi }\end{array}$ & $\begin{array}{l}\text { Melengkapi dan } \\
\text { mengintegrasikan } \\
\text { aplikasi sistem } \\
\text { Informasi } \\
\text { PT.Virgina } \\
\text { Estetika (Farina } \\
\text { Beauty Clinic) } \\
\text { serta penyediaan } \\
\text { disetiap divisi } \\
\text { klinik }\end{array}$ & $\begin{array}{l}\text { Aplikasi } \\
\text { database } \\
\text { terdistribusikan }\end{array}$ \\
\hline
\end{tabular}

\section{PEMETAAN APLIKASI}

Berdasarkan hasil penyusunan kebutuhan aplikasi di PT. Virgina Estetika (Farina Beauty Clinic), penulis merumuskan kebutuhan aplikasi tersebut ke dalam bentuk Strategic Grid Mc Farlan Analysis, dimana setiap aplikasi digolongkan berdasarkan pengaruh aplikasi tersebut yaitu Strategic, Key, Operational, High Potential dan Support.

\section{a. Pemetaan Kuadran Strategic}

Terdapat beberapa aplikasi yang dikategorikan kedalam kuadran strategic, dimana aplikasi-aplikasi tersebut berfungsi sebagai pusat pelayanan untuk memudahkan proses bisnis dan transaksi bisnis serta menentukan langkah bisnis yang berpengaruh terhadap kesuksesan PT. Virgina Estetika (Farina Beauty Clinic) Karawang di masa depan. Adapun aplikasi- aplikasi yang dikategorikan dalam kuadran strategic adalah:

- Aplikasi Expert System Diagnosa Penyakit.

- Aplikasi Supply Chain Management.

- Aplikasi Sistem Informasi Eksekutif.

- Aplikasi Sistem Informasi Pelayanan Kesehatan

\section{b. Pemetaan Kuadran Key Operational}

Dalam kuadran key operational terdapat beberapa aplikasi-aplikasi yang digunakan untuk kelangsungan proses bisnis di PT. Virgina Estetika (Farina Beauty Clinic) Karawang Adapun aplikasi- aplikasi yang dikategorikan dalam kuadran ini adalah:

- Aplikasi Rekam Medis

- Aplikasi Keuangan 
- Aplikasi Apotek

- Aplikasi Inventaris

- Aplikasi Database Terdistribusi

\section{c. Pemetaan Kuadran High Potential}

Dalam kuadran high potential dikategorikan sebagai aplikasi-aplikasi inovatif yang menjadi competitive value dan berpotensi untuk kelangsungan bisnis PT. Virgina Estetika (Farina Beauty Clinic) Karawang . Adapun aplikasi yang dikategorikan ke dalam kuadran ini adalah Aplikasi SDM Klinik.

\section{d. Pemetaan Kuadran Support}

Dalam kuadran support dikategorikan sebagai aplikasi- aplikasi yang bias mendukung proses bisnis namun tidak berpengaruh pada kelangsungan bisnis PT. Virgina Estetika (Farina Beauty Clinic) Karawang. Adapun aplikas-aplikasi yang dikategorikan ke dalam kuadran ini adalah:

- Aplikasi Decission Support System Kinerja PT. Virgina Estetika (Farina Beauty Clinic).

- Aplikasi sistem dokumen PT. Virgina Estetika (Farina Beauty Clinic).

\begin{tabular}{|c|c|}
\hline STRATEGIC & HIGH POTENTIAL \\
\hline $\begin{array}{l}\text { - Aplikasi Expert System Diagnosa } \\
\text { Penyakit } \\
\text { - Aplikasi Supply Chain Management } \\
\text { - Aaplikasi Sistem Infromasi } \\
\text { Eksekutif } \\
\text { - Aplikasi Sistem Informasi Pelayanan } \\
\text { Kesehatan }\end{array}$ & $\begin{array}{l}\text { - Aplikasi SDM PT. Virgina Estetika } \\
\text { (Farina Beauty Clinic) } \\
\text { - Aplikasi Website PT. Virgina } \\
\text { Estetika (Farina Beauty Clinic) }\end{array}$ \\
\hline $\begin{array}{l}\text { - Aplikasi Rekam Medis } \\
\text { - } \text { Aplikasi Keuangan } \\
\text { - Aplikasi Apotek } \\
\text { - Aplikasi Inventaris } \\
\text { - } \text { Aplikasi Database Terdistribusi }\end{array}$ & $\begin{array}{l}\text { - Aplikasi Decission System Kinerja } \\
\text { PT. Virgina Estetika (Farina Beauty } \\
\text { Clinic) } \\
\text { - Aplikasi Sistem Dokumen PT. } \\
\text { Virgina Estetika (Farina Beauty } \\
\text { Clinic) }\end{array}$ \\
\hline KEY OPERATIONAL & $\begin{array}{l}\text { SUPPORT } \\
\end{array}$ \\
\hline
\end{tabular}

Gambar 6

Aplikasi Portofolio

\section{KESIMPULAN}

Berdasarkan hasil penelitian yang penulis lakukan mengenai perencanaan strategis sistem informasi Klinik kecantikan dengan ward and peppard model di Karawang, maka dapat disimpulkan bahwa, Klinik kecantikan farina beauty clinic merupakan organisasi atau perusahaan yang bergerak di bidang penyedia jasa pelayanan kecantikan wajah dan tubuh.

Untuk bisa mendapatkan keunggulan bersaing dan dapat bertahan dalam persaingan yang ketat, strategi yang dapat dilakukan Klinik kecantikan Farina Beauty Clinic Karawang adalah dengan differentiation dan cost reduction. Salah satu hal yang bisa dilakukan untuk cost-reduction adalah dengan menjadikan proses bisnis yang ada di Farina Beauty Clinic menjadi lebih efisien, salah satu hal yang bisa dimanfaatkan untuk efisiensi adalah teknologi informasi dengan perencanaan yang matang sehingga dapat membantu, mendukung dan selaras dengan business objective dari Farina Beauty Clinic. 


\section{DAFTAR PUSTAKA}

[1] Budi Rahayu, 2009, Perencanaan Strategis Sistem Informasi (Studi Kasus : PT Asta Anugerah Sejahtera), Tesis STMIK LIKMI.

[2] Leitch, Robert A, 1983, Accounting Infromation Systems, Prentice Hall.

[3] Jane P. Laudon, Kenneth C.Laudon, 2017, Management Information Systems, pearson, England.

[4] Ward, John \& Peppard, Joe, 2003, Strategic Planning for Information System, Chichester: John Willey \& Sons, Ltd, USA.

[5] Galliers, R.D., Leidner, D.E., 2003, Strategic Information Management, Elsivier Butterwoth Heineman, Burlington.

[6] Orna, Elizabeth, 2008, Practical Information Policies, Gower Publishing Ltd,

[7] Dewan Pelawi, Franky, Charles Willy, Bobby Irwanza, 2011, Perencanaan Strategi Sistem Dan Teknologi Informasi Pada PT. Tripuri Mitra Nobelindo, ComTech Vol.2 No. 1 Juni 2011: 341-355. 